Jpn. J. Pharm. Health Care Sci.

ノート 27(6) 583-588(2001)

\title{
輸液容器及び輸液セットにおけるインスリン吸着とその防止
}

\author{
山之内恒昭 $\dagger^{*} \dagger^{1}$, 青野珠可 $\dagger^{1}$ ，三村泰彦 $\dagger^{1}$ ，足立伊佐雄 $\dagger^{1}$ ，角田美鈴市 ${ }^{2}$ ，長澤智子 $\dagger^{2}$ ， \\ 森田未香 $\dagger^{2}$ ，矢野彩子 $\dagger^{2}$ ，林 史朗 $\dagger^{2}$ ，大門良男 $\dagger^{2}$ \\ 富山医科薬科大学附属病院薬剂部 $\dagger^{1}$, 同検査部 $\dagger^{2}$
}

\section{Adsorption of Insulin to Infusion Containers and Infusion Sets and Its Prevention}

\author{
Tsuneaki Yamanouchi ${ }^{*} \uparrow^{1}$, Shuka Aono $\uparrow^{1}$, Yasuhiko Mimura $\uparrow^{1}$, Isao Adachi $\uparrow^{1}$, \\ Misuzu Kakuda $\uparrow^{2}$, Tomoko Nagasawa $\dagger^{2}$, \\ Mika Morita $\dagger^{2}$, Saiko Yano $\dagger^{2}$, Shirou Hayashi $\uparrow^{2}$ and Yoshio Daimon $\dagger^{2}$ \\ Department of Hospital Pharmacy $\dagger^{1}$, Department of Clinical Laboratory $\dagger^{2}$, \\ Toyama Medical and Pharmaceutical University
}

$\left[\begin{array}{l}\text { Received April 3, } 2001 \\ \text { Accepted September 17, 2001 }\end{array}\right]$

\begin{abstract}
We studied the effect of total-vitamin addition, insulin concentration and the exchange of infusion containers on the adsorption of insulin to infusion containers and infusion sets (line and filter). The adsorption of insulin to infusion containers and infusion sets decreased by the addition of total-vitamin injection, and the addition of a half-volume of total-vitamin injection also gave a similar result.

In the absence of total-vitamin injection, adsorption to the infusion containers was not influenced by the concentrations of insulin ( 5-40 units). However, the adsorption to infusion sets decreased as the concentration of insulin increased. In the presence of total-vitamin injection, adsorption to infusion containers and infusion sets decreased by the same degree, but was not influenced by the change in concentrations of insulin ( $5-40$ units).

When the infusion container without total-vitamin injection was changed to a new one with total-vitamin injection, a rapid increase in the insulin outflow of the infusion set was observed. The increase in the insulin outflow could be prevented by the addition of a half-volume of total-vitamin injection into both infusion containers. These results suggest that the constant addition of a half-volume of total-vitamin injection containing surfactants into each infusion container is an effective way to slightly change the insulin outflow of infusion set when two containers a day are needed.
\end{abstract}

Keywords — insulin, adsorption, infusion containers, infusion sets, total-vitamin injection

\section{緒言}

糖尿病治療においてインスリンは一般的に皮下注射さ れるが，ケトアシドーシスの治療，手術後や糖尿病患者 の高カロリー輸液時における血糖值管理等には，インス リンを輸液中に添加する少量持続点滴が広く行われてい
る.この場合, 輸液中のインスリンが容器, 輸液ライ ン, フィルター等の輸液器材へ吸着することが問題とさ れ, 輸液中にアルブミン, 脂溶性ビタミン剤, 総合ビタ ミン剂，界面活性剂等を添加することによりその吸着が 抑制されることが報告されているが，使用されている輸 液容器の材質, 輸液器材, 輸液の種類などにより吸着率

$\dagger^{1,2}$ 富山市杉谷2630 ; 2630, Sugitani, Toyama-shi, 930-0194 Japan 
はさまざまである1-6)，そこで著者らは今回，実際の臨 床現場に即した状態において，当院で使用されている輸 液容器および輸液セットに対するインスリンの吸着につ いて, 総合ビタミン剤添加による影響, インスリン添加 量の違いによる影響，輸液容器交換による影響について 検討した.

\section{方法}

\section{1. 試料}

輸液容器はエチレン酢酸ビニル（EVA）製のユニカ リック N1000mL（Lot No.000518LN，テルモ(怢) を使用 した。インスリンはヒューマリン R 注 U-40（Lot No. 3 NF62MA，日本イーライリリー(侏)，総合ビタミン剂は M.V.I. 注（Lot No.02002，エスエス製薬(株)），ネオラミ ンマルチ V (Lot No.705320，日本化薬(䛈) を使用した。 輸液セットはフィルターがポジダイン・ナイロン66製, ラインがポリ塩化ビニル（PVC）製のポール輸液フィル ターELD セット（ELD-SF-T15U 2, Lot No.000204, 日 本ポール(株) を使用した。その他，リン酸二水素ナトリ ウム, リン酸水素二ナトリウム（試薬特級, ナカライテ スク(株)，牛血清アルブミン（Fraction V, Lot No. $16 \mathrm{H}$ 0781，Sigma）を使用した。

\section{2. 総合ビタミン剤添加による影響}

ユニカリック Nの M.V.I. 無添加群, $2.5 \mathrm{~mL}$ 添加群お よび $5 \mathrm{~mL}$ 添加群の 3 群で比較した. M.V.I. 添加群は M.V.I. を添加後10回転倒混和し，インスリン添加まで 室温で30分間放置した。また, M.V.I. 添加群は M.V.I. 添加後から実験終了まで点滴用遮光カバーをかけて遮光 した． 3 群それぞれにインスリン 20 単位を添加し，ただ ちに10回転倒混和し，室温で 1 時間放置した。 1 時間後 輸液セットを輸液容器に接続し，輸液セット先端より滴 下し始めた時点を 0 時間とした。サンプリングは輸液容 器混注口と輸液セット先端の 2 カ所とし， 0, 30 分， 1，3，6，12時間後にサンプリングし，それぞれ のインスリン濃度を測定した。

インスリンのシリンジへの吸着を考慮し，あらかじめ インスリン原液で30分間飽和させたシリンジをインスリ ン添加に使用し，サンプリング時のシリンジは検体でと もあらいを行った後サンプリングに使用した。また，す べての実験において滴下速度は12時間ごとに輸液容器を 交換するということを想定し $1.4 \mathrm{~mL} / \mathrm{min}$ とした.

\section{3. インスリン添加量の違いによる影響}

ユニカリック Nの M.V.I. 無添加群, $2.5 \mathrm{~mL}$ 添加群の 2 群で比較した。インスリンの添加量を $5 ， 10 ， 20 ４ 0$
単位とし，前の実験と同様な方法で行った。サンプリン グは輸液容器混注口と輸液セット先端の 2 カ所と し，0，5，15，30分，1，3，6時間後にサンプリン グし，それぞれのインスリン濃度を測定した。

\section{4. 輸液容器交換による影響（1）}

ユニカリック $\mathrm{N}$ の M.V.I. 無添加輸液から無添加輸液 $へ$, M.V.I. 無添加輸液加 $5 \mathrm{~mL}$ 添加輸液へ, M.V.I. 5 $\mathrm{mL}$ 添加輸液加無添加輸液へ, M.V.I. 2. $5 \mathrm{~mL}$ 添加輸液 から $2.5 \mathrm{~mL}$ 添加輸液へ，それぞれ容器交換を行い 4 群 で比較した．インスリンの添加量は容器あたり20単位と した，それぞれ前者で 12 時間滴下した輸液セットをその まま使用し，後者の輸液に容器交換を行い，交換後の容 器内の輸液が輸液セット先端より滴下し始めた時点を 0 時間とした。サンプリングは輸液セット先端の 1 カ所の みとし，交換前 30 分おょび交換後 $0 ， 5 ， 15 ， 30$ 分， $1 ， 3 ， 6$ 時間後にサンプリングし，それぞれのイ ンスリン濃度を測定した。

\section{5. 輸液容器交換による影響 $(2$ )}

ユニカリック $\mathrm{N}$ の総合ビタミン剂無添加輸液から開 始し, 総合ビタミン剂添加輸液と無添加輸液を 12 時間ご とに交互に交換し，その間輸液セットは交換せずに同じ ものを使用するという条件下で行った。総合ビタミン剤 は M.V.I. とネオラミンマルチV（NMV）を使用し，イ ンスリンの添加量は容器あたり20単位とした。総合ビ夕 ミン剂無添加輸液加添加輸液への交換前後におけるイ ンスリン濃度を 1 日目，2 日目それぞれ測定した。サン プリングは輸液セット先端の 1 カ所のみとし, 1 日目, 2 日目それぞれ交換前30分㧍上び交換後 $0 ， 5 ， 15 ， 30$ 分， 1，3，6 時間後にサンプリングし，それぞれのイ ンスリン濃度を測定した。

\section{6. インスリンの定量}

インスリンの定量は酵素免疫法 (EIA) による測定キッ ト（Eテスト「TOSOH」I，東ソー(陎) 㧍よびエンザイ ムイムノアッセイアナライザー（AIA-1200XL，東ソー (侏)を用いて行った。サンプルが高濃度であるため，測 定可能な濃度範囲まで希䣋を必要とした。この操作中 に，試験管等にインスリンが吸着するのを防止するため に，0.5\%牛血清アルブミンを含むリン酸緩衝液（pH 7.4）を用いてサンプルを希釈した後，インスリンの定 量を行った。

\section{7. 統計処理}

得られた結果はすべて，平均值士標準偏差（mean士 
S.D.）にて示した。 また 2 群間の比較にはStudent の $\mathrm{t}$ 検定を，3群間以上の比較にはANOVA および Bonferroni の多重比較検定（Dunnett 型）を用い， $\mathrm{p}<0.05$ を有 意差ありと判定した。

\section{結果}

\section{1. 総合ビタミン剂添加による影響}

輸液容器内のインスリン濃度比（理論添加濃度に対す る溶液中濃度の比率）（\%）の経時的変化を Fig. 1 (a) に示す。輸液容器内でのインスリン濃度比は M.V.I. 無 添加群では 1 時間後で76\%，6時間後で72\%であった。

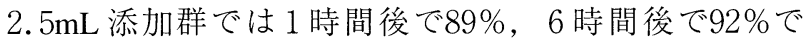
あった． $5 \mathrm{~mL}$ 添加群では 1 時間後で $91 \% ， 6$ 時間後で 92\%であった。輸液セット先端流出液でのインスリン濃 度比の経時的変化を Fig. 1（b）に示す．輸液セット先 端流出液のインスリン濃度比は M.V.I.無添加群では 1 時 間後で $57 \% ， 6$ 時間後で $77 \%$ あったた. $2.5 \mathrm{~mL}$ 添加群 では 1 時間後で $94 \% ， 6$ 時間後で95\%であった。 $5 \mathrm{~mL}$ 添加群では 1 時間後で $89 \% ， 6$ 時間後で95\%であった。 このように M.V.I.添加群では輸液七ットにおけるインス リンの吸着は約 1 時間で飽和に達した。輸液容器内，あ るいは輸液セット先端流出液のインスリン定量から評価 したインスリンの輸液容器や輸液セットへの吸着は, M.V.I.無添加群に比べ添加群では有意に抑制され，その 抑制の程度は M.V.I. 添加量が2. $5 \mathrm{~mL}$ でも $5 \mathrm{~mL}$ でも差は 認められなかった.

\section{2. インスリン添加量の違いによる影響}

ユニカリック $\mathrm{N}$ の M.V.I.無添加群, $2.5 \mathrm{~mL}$ 添加群の 2 群で，インスリンをそれぞれ 5，10，20，40単位添加 した時の輸液容器内でのインスリン濃度比の経時的変化 をそれぞれ Fig. 2 (a)，Fig. 2 (b) に示す. M.V.I.無添 加群の輸液容器内ではインスリンの添加量が 5 ４0単位 の間でのインスリン濃度比はそれぞれ 1 時間後で 65，66，73，61\%，6 時間後で56，61，72，68\%とイン スリン添加量の違いによる差は認められなかった。 M. V.I.添加群の輸液容器内では，インスリンの添加量が 5 ４0単位の間でのインスリン濃度比はそれぞれ 1 時間 後で $81 ， 80 ， 85 ， 81 \% ， 6$ 時間後で $86 ， 84 ， 91 ， 88 \%$ と M.V.I.無添加群に比べ添加群ではすべての場合で吸着率 は抑制されているが，インスリン添加量の違いによる差 は認められなかった。

また, M.V.I.無添加群, $2.5 \mathrm{~mL}$ 添加群の輸液セット先 端流出液でのインスリン濃度比の経時的変化をそれぞれ

Fig. 3 (a)，Fig. 3 (b) に示す. M.V.I.無添加群の輸液 セット先端流出液では 6 時間後のインスリン濃度比はイ ンスリンの添加量が5〜40単位でそれぞれ47\%, 63\%，77\%，79\%と，インスリンの添加量が多くなるに つれて吸着率は抑制された. M.V.I.添加群の輸液セット 先端流出液では，インスリンの添加量が $5 \sim 40$ 単位の間 でのインスリン濃度比はそれぞれ 1 時間後で 81，80，91，90\%，6 時間後で90，91，94，94\%と無添 加群に比べて吸着率は抑制されているが，インスリン添 加量の違いによる差は認められなかった。また，約 1 時 (a)

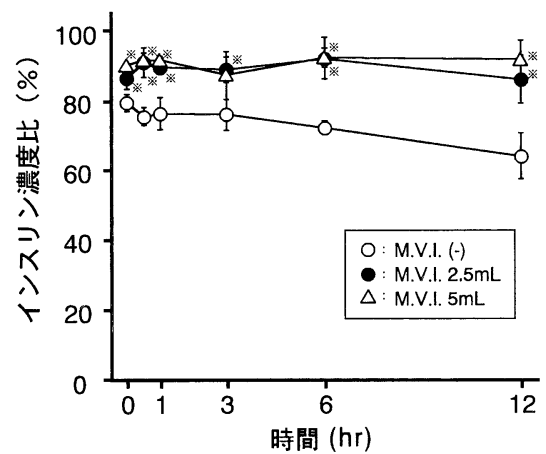

(b)

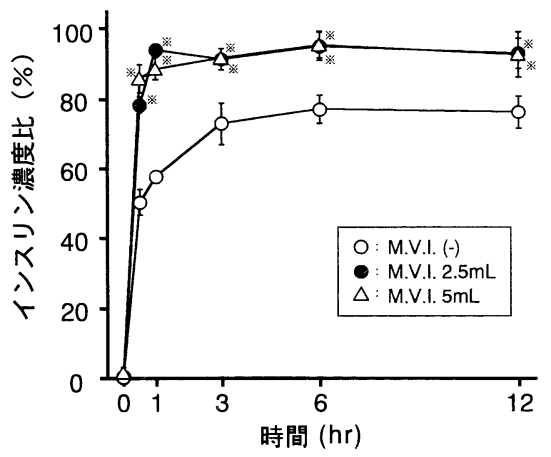

Fig. 1.インスリン濃度比に及ぼす M.V.I.添加の影響

(a) 輸液容器内のインスリン測定から見た場合

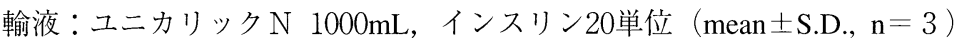
$*_{\mathrm{p}}<0.05$ vs M.V.I. $(-)$

（b）輸液セット先端流出液のインスリン測定から見た場合

輸液：ユニカリックN $1000 \mathrm{~mL}$ ，インスリン20単位（mean \pm S.D., $\mathrm{n}=3$ ) ※ $\mathrm{p}<0.05$ vs M.V.I. (-) 
(a)

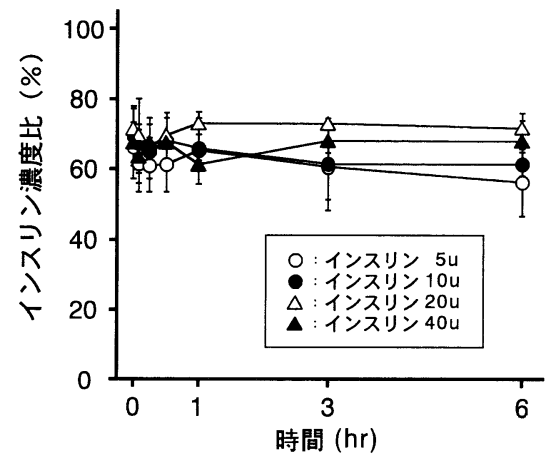

(b)

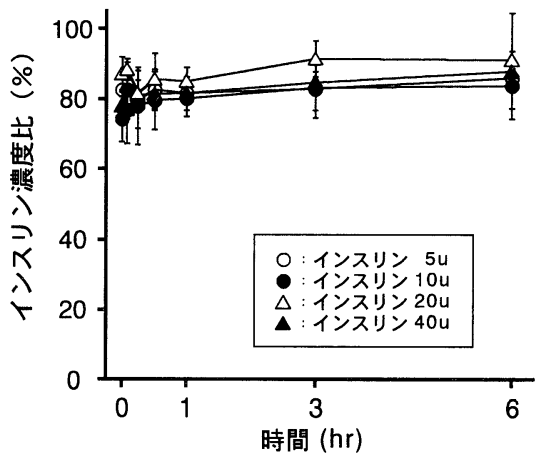

Fig.2. インスリン濃度比に及ぼすインスリン添加量の影響

(a) 輸液容器内のインスリン測定から見た場合 輸液：ユニカリック $\mathrm{N} 1000 \mathrm{~mL}$, 総合ビタミン剂：無添加 (mean \pm S.D., $\mathrm{n}=3$ )

（b）輸液容器内のインスリン測定から見た場合

輸液：ユニカリックN $1000 \mathrm{~mL}$,

総合ビタミン剂：M.V.I. 2.5mL（mean \pm S.D., $\mathrm{n}=3$ )

(a)

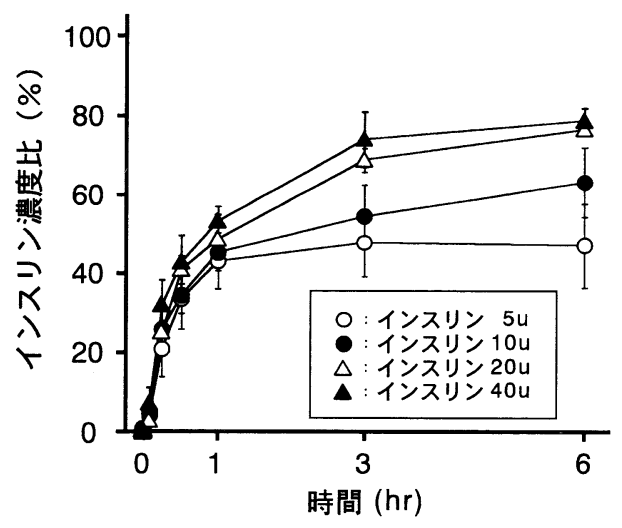

(b)

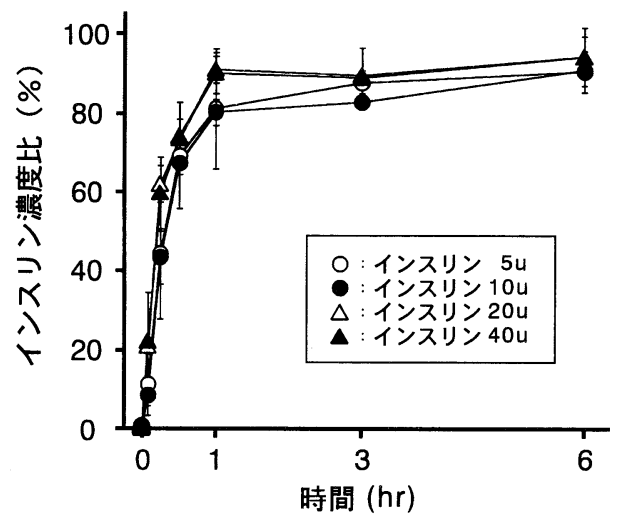

Fig.3．インスリン濃度比に及ぼすインスリン添加量の影響

(a) 輸液セット先端流出液のインスリン測定から見た場合

輸液：ユニカリック $\mathrm{N} 1000 \mathrm{~mL}$,

総合ビタミン剂：無添加 (mean \pm S.D., $\mathrm{n}=3$ )

（b）輸液セット先端流出液のインスリン測定から見た場合

輸液：ユニカリック $\mathrm{N} 1000 \mathrm{~mL}$,

総合ビタミン剤：M.V.I. 2.5mL（mean \pm S.D., $\mathrm{n}=3$ )

間で輸液セットにおけるインスリンの吸着は飽和されて いた。

\section{3. 輸液容器交換による影響 $(1)$}

輸液容器交換前後における輸液セット先端流出液のイ ンスリン濃度比の経時的変化を Fig. 4 に示す. M.V.I. 無添加輸液から $5 \mathrm{~mL}$ 添加輸液へ容器交換した場合の み，短時間でインスリン濃度の急激な増加が起こり，イ

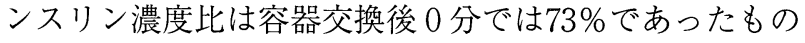
が，15分後で151\%とピーク值に達し，1 時間後で $96 \%$ に減少した。他の 3 群に扔いては輸液容器交換前後でイ ンスリン濃度の変動はほとんど見られなかった。

\section{4. 輸液容器交換による影響 ( 2)}

総合ビタミン剂無添加輸液と添加輸液を12時間ごとに 容器交換を繰り返し, 総合ビタミン剂無添加輸液から添 


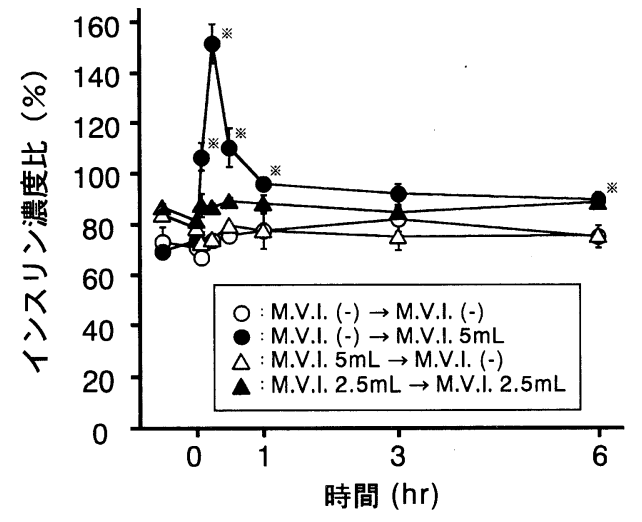

Fig.4. 輸液セット先端流出液のインスリン濃度 比に及ぼす輸液容器交換の影響 $(1$ )

輸液：ユニカリック $\mathrm{N} 1000 \mathrm{~mL}$ ，インス リン20単位 (mean \pm S.D., $\mathrm{n}=3$ ) $*_{\mathrm{p}}<0.05$ vs M.V.I. $(-) \rightarrow$ M.V.I. $(-)$

加輸液へ容器交換した場合のインスリン濃度の変動を 2 日目まで測定した。1日目および 2 日目の輸液容器交換 前後における輸液セット先端流出液のインスリン濃度比 の経時的変化を Fig. 5 に示す. インスリン濃度比は 1 日目の総合ビタミン剂無添加輸液から添加輸液への容器 交換において，M.V.I.では交換後 0 分で67\%，15分で 150\%，NMVでは交換後０分で70\%，15分で149\%とい ずれも容器交換後15分でピークとなった。 2 日目の総合 ビタミン剤無添加輸液から添加輸液への容器交換では M.V.I.では 0 分で78\%，15分で102\%, NMVでは 0 分で 75\%，15分で104\%と 1 日目に比べてインスリン濃度の
変動は少なかった。また 1 日目，2日目ともM.V.I.と NMV でインスリン濃度の変動に差はみられなかった。

\section{考察}

インスリンの容器や輸液器材への吸着についてはこれ までに多くの報告がなされ，容器や輸液器材の材質や輸 液組成，混合後の振盪等によっても吸着率がかなり異 なっている吕).インスリンの吸着抑制についても，ア ルブミン, 総合ビタミン鼡, 脂溶性ビタミン剂, 界面活 性剂の添加等によりインスリンの吸着が抑制されたとい う報告 ${ }^{2-6}$ があるが，今回の実験結果もそれらの報告と 同様に界面活性剤を含む総合ビタミン剤の添加によっ て，インスリンの吸着が抑制された. インスリンの定量 法についても，酵素免疫法 (EIA ${ }^{1,3)}$, HPLC 法 ${ }^{4-6)}$, ラ ジオイムノアッセイ法 $(\mathrm{RIA})^{2)}$ な゙，報告によりさまざ まである．われわれは今回酵素免疫法で測定を行った が，今後は他の測定法との相関性も検討する必要がある と考えられる。

輸液容器内および輸液セット先端流出液のインスリン 測定から見たインスリンの吸着は, M.V.I.無添加群に比 べ添加群では抑制され，M.V.I.の添加量を通常量の 5 $\mathrm{mL}$ から半量にしても同様の結果が得られた. M.V.I.無 添加群の輸液容器内ではインスリン添加量の違いによる 影響を受けなかったが，輸液セット先端流出液ではイン スリン添加量が多くなるにつれて吸着率は抑制された。 M.V.I.添加群では輸液容器内, 輸液セット先端流出液と もインスリン添加量の違いによる影響はなく，同程度に 吸着抑制された。
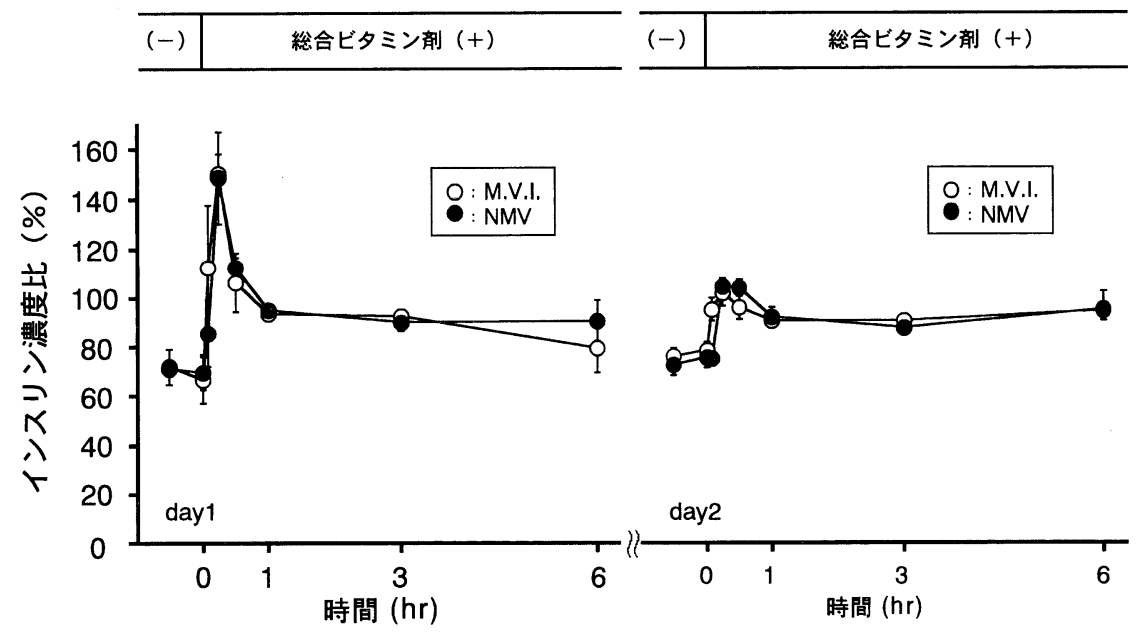

Fig. 5. 輸液セット先端流出液のインスリン濃度比に及ぼす輸液容器交換 の影響 $(2)$

輸液：ユニカリックN $1000 \mathrm{~mL} ，$ インスリン20単位（mean \pm S.D., $\mathrm{n}=3$ ) 
輸液容器交換では M.V.I. 無添加輸液から $5 \mathrm{~mL}$ 添加輸 液へ交換した場合にのみ，輸液セット先端流出液におい てインスリン濃度が約 2 倍へと急激な上昇が起こった が，他の 3 群においては輸液容器交換前後でインスリン 濃度の変動はほとんどなかった。この上昇は，インスリ ンで吸着飽和された輸液セットからのインスリンの溶出 のためと考えられる。実際の臨床現場においては, 高力 ロリー輸液時に総合ビタミン剤添加輸液と無添加輸液を 12時間ごとに交互に使用する場合も多く, 総合ビタミン 剤無添加輸液から添加輸夜へ容器交換した際にインスリ ン投与量が一時的に多くなり, 血糖值が変動する可能性 があるので注意する必要があると考えられる。さらに容 器交換を継続し，2 日目の総合ビタミン剂無添加輸液か ら添加輸液へ交換した際には，インスリン濃度の増加は 1 日目に比べかなり少なくなった。一度輸液セットに吸 着した総合ビタミン鼡は総合ビタミン剂無添加輸液に交 換してもかなりの部分が吸着されたまま残っているもの と思われる。このことから新しい輸液セットに交換した 際には特に注意が必要であると考えられる。

M.V.I.はインスリンの吸着抑制に対しては半量でも十 分であることから, 総合ビタミン剤添加輸液と無添加輸 液を12時間ごとに交互に使用する場合，インスリンの投 与量の変動を少なくするために総合ビタミン剤を常に半 量ずつ輸液容器に添加することが有効であると考えられ る.また，アルブミン添加によってもインスリンの吸着 は抑制されることが報告されているる の添加については, 適応外使用のため保険請求上の問 題, 分割使用による污染の可能性等の問題もある. 総合 ビタミン剂は臨床上輸液中に混合される場合が多く，ア
ルブミンと比較して十分なインスリン吸着抑制効果を持 つ2,3)ことからも，インスリン吸着抑制に対して総合ビ タミン剤を輸夜中に添加することは有用であると考えら れる．また，インスリンの吸着を抑制するために，輸液 セットを交換した際にはまず総合ビタミン剤添加輸液を 使用して, 輸液セットに対する吸着を総合ビタミン剂で 飽和させた後, 総合ビタミン剤無添加輸液に交換すると いったことも有効であると考えられる。

謝辞 今回の実験に際し，輸液掞よび輸液セットを提供し ていただいたテルモ(侏)，日本ポール(株に深謝いたします。

\section{引用文献}

1）吉田浩幸, 内藤重穂, 田中彦衛, ヒト型インスリ ンの輸液容器等への吸着挙動, 医薬ジャーナル, 24, 1031-1034(1988).

2）丹下マリ子, 柴部敏, 近藤俊夫, 尾山秀樹, イン スリンの輸液容器等への吸着, 医薬ジャーナル, 31, 392-397 (1995).

3）菅谷量俊，西澤健司，清水哲，村田和也，平野公 戟，高カロリー輸液バッグ・輸液セットに打ける インスリンの吸着㧍よび吸着抑制についての検 討, Pharm. Tech. Japan, 9, 825-830 (1993).

4）峰本正夫, 浅原稔生, 前田宏子, 野田浩司, イン シュリンのソフトバッグ輸液容器への吸着とその 防止の試み, 病院薬学, 11, 431-438(1985).

5) 浅川直樹, インシュリンの容器への吸着防止につ いて, 薬学雑誌, 104, 311-315(1984).

6) 前田豊, 服部順一, 三浦康彦, 塩見武雄, 輸液中 に扔けるインシュリンの経時変化（第 2 報), “近 畿中央病院研究業績集1985”, 1986, pp.49-55. 